University of Nebraska - Lincoln

DigitalCommons@University of Nebraska - Lincoln

Publications from USDA-ARS / UNL Faculty

U.S. Department of Agriculture: Agricultural

Research Service, Lincoln, Nebraska

2013

\title{
Hydrology and water quality of a field and riparian buffer adjacent to a mangrove wetland in Jobos Bay watershed, Puerto Rico
}

\author{
C. O. Williams \\ Charles E. Kellogg National Soil Survey Laboratory \& Research \\ R. Lowrance \\ Southeast Watershed Research Laboratory, Richard.Lowrance@ars.usda.gov \\ D. D. Bosch \\ Southeast Watershed Research Laboratory \\ J. R. Williams \\ Texas A\&M University \\ E. Benham \\ Charles E. Kellogg National Soil Survey Laboratory \& Research \\ See next page for additional authors
}

Follow this and additional works at: https://digitalcommons.unl.edu/usdaarsfacpub

Williams, C. O.; Lowrance, R.; Bosch, D. D.; Williams, J. R.; Benham, E.; Dieppa, A.; Hubbard, R.; Mas, E.; Potter, T.; Sotomayor, D.; Steglich, E. M.; Strickland, T.; and Williams, R. G., "Hydrology and water quality of a field and riparian buffer adjacent to a mangrove wetland in Jobos Bay watershed, Puerto Rico" (2013). Publications from USDA-ARS / UNL Faculty. 2104.

https://digitalcommons.unl.edu/usdaarsfacpub/2104

This Article is brought to you for free and open access by the U.S. Department of Agriculture: Agricultural Research Service, Lincoln, Nebraska at DigitalCommons@University of Nebraska - Lincoln. It has been accepted for inclusion in Publications from USDA-ARS / UNL Faculty by an authorized administrator of DigitalCommons@University of Nebraska - Lincoln. 


\section{Authors}

C. O. Williams, R. Lowrance, D. D. Bosch, J. R. Williams, E. Benham, A. Dieppa, R. Hubbard, E. Mas, T. Potter, D. Sotomayor, E. M. Steglich, T. Strickland, and R. G. Williams 


\title{
Hydrology and water quality of a field and riparian buffer adjacent to a mangrove wetland in Jobos Bay watershed, Puerto Rico
}

\author{
C.O. Williams ${ }^{c}$, R. Lowrance ${ }^{\mathrm{a}, *}$, D.D. Bosch ${ }^{\mathrm{a}}$, J.R. Williams ${ }^{\mathrm{b}}$, E. Benham ${ }^{\mathrm{c}}$, A. Dieppa ${ }^{\mathrm{d}}$, R. Hubbard ${ }^{\mathrm{a}}$, \\ E. Mas ${ }^{\text {e }}$, T. Potter ${ }^{\mathrm{a}}$, D. Sotomayor ${ }^{\mathrm{f}}$, E.M. Steglich ${ }^{\mathrm{b}}$, T. Strickland ${ }^{\mathrm{a}}$, R.G. Williams ${ }^{\mathrm{a}}$ \\ a Southeast Watershed Research Laboratory, 2379 Rainwater Road, Tifton, GA 31794, United States \\ ${ }^{\mathrm{b}}$ Blackland Research Center, Texas AE'M University, Temple, TX 76502, United States \\ ${ }^{c}$ Charles E. Kellogg National Soil Survey Laboratory \& Research, 100 Centennial Mall North, Lincoln, NE 68508, United States \\ ${ }^{\mathrm{d}}$ National Estuarine Research Reserve, Call Box B, Aguirre, PR 00704, United States \\ e Natural Resource Conservation Service-Caribbean, 2200 Pedro Albizu Campos Ave 23, Mayaguez, PR 00680, United States \\ ${ }^{\mathrm{f}}$ University of Puerto Rico-Mayagüez, P.O. Box 9000, Mayagüez, PR 00681, United States
}

\section{A R T I C L E I N F O}

\section{Article history:}

Received 24 January 2012

Received in revised form

25 September 2012

Accepted 28 September 2012

Available online 11 December 2012

\section{Keywords:}

Mangrove wetlands

Water quality

Hydrology

Riparian buffers

Nitrogen

Phosphorus

Sediment

APEX

REMM

\begin{abstract}
A B S T R A C T
Agriculture in coastal areas of Puerto Rico is often adjacent to or near mangrove wetlands. Riparian buffers, while they may also be wetlands, can be used to protect mangrove wetlands from agricultural inputs of sediment, nutrients, and pesticides. We used simulation models and field data to estimate the water, nitrogen, and phosphorus inputs from an agricultural field and riparian buffer to a mangrove wetland in Jobos Bay watershed, Puerto Rico. We used the Agricultural Policy/Environmental eXtender (APEX) and the Riparian Ecosystem Management Model (REMM) models sequentially to simulate the hydrology and water quality of the agricultural fields and an adjacent riparian buffer, respectively. Depth to the water table surface was measured monthly at numerous sites in both field and riparian areas and were used with recording well data from outside the field to estimate daily water table depths in the field and riparian buffer and to calibrate field-scale hydrologic processes. Calibration and validation of the models were successful for the riparian buffer and in three of four field quadrants. In these areas the average simulated depth to water table for the field and the riparian buffer were within $\pm 7 \%$ of field estimated water table depths. Over the 3-year study period, the riparian buffer represented by REMM reduced agricultural loadings to the mangrove wetland by $24 \%$ for sediment yield, and about $30 \%$ for total nitrogen and phosphorus. Simulations indicated that tropical storms and hurricanes played an important role in water and nutrient transport on this site contributing at least $63 \%$ of total sediment and nutrient loads.
\end{abstract}

Published by Elsevier B.V.

\section{Introduction}

Because of the limited ability to monitor watershed scale inputs to coastal waters and wetlands, simulation modeling of these inputs is needed (Rollo and Robin, 2010). On the coast of Puerto Rico, anthropogenic disturbances have been identified as major contributors to the deterioration of mangrove wetlands, shallow water coral reefs, and seagrass beds (Zitello et al., 2008). Agriculture in coastal zones of Puerto Rico is often adjacent to or near mangrove wetlands. Riparian buffers, while they may also be wetlands, can be used to protect mangrove wetlands from inputs of sediment, nutrients, and pesticides from agriculture.

\footnotetext{
* Corresponding author. Tel.: +1 229386 3894; fax: +1 2293867294

E-mail address: Richard.Lowrance@ars.usda.gov (R. Lowrance).
}

In 2007, the Jobos Bay watershed, Puerto Rico was selected as the first tropical Conservation Effects Assessment Project (CEAP) Special Emphasis Watershed due to its proximity to the Jobos Bay National Estuarine Research Reserve (NERR) (Zitello et al., 2008). CEAP is a multi-agency government effort to quantify the impacts of USDA conservation practices on water quality. The Jobos Bay CEAP was implemented to determine the effects of agricultural conservation on coastal wetland ecosystems and was motivated in part by U.S. Coral Reef Task Force efforts to reduce threats to mangrove wetlands and shallow water coral reefs. The project was a collaborative effort between USDA-Agricultural Research Service, USDA-Natural Resources Conservation Service (USDANRCS), National Oceanic and Atmospheric Administration (NOAA), the Puerto Rico Department of Natural Resources, and the University of Puerto Rico-Mayaguez.

Riparian ecosystems are important tools in controlling nonpoint source pollution (Lowrance et al., 1997) and have been established 
in agricultural landscapes to reduce the mass of sediments and nutrients moving to receiving waters (Lee et al., 2003; Lowrance et al., 2001, 2007; Lowrance and Sheridan, 2005). Because of concerns about the effects of agriculture on the mangrove wetlands, a riparian buffer was installed between the farm fields and the mangrove wetlands on Jobos NERR property in the early 2000s.

Models that estimate the effects of agricultural conservation practices on water quantity and quality are increasingly important tools for short- and long-term assessments (Williams and Sharpley, 1989; Lowrance et al., 2000; Williams et al., 2008). Because there were only limited data from the study area and no data on the site before the riparian forest buffer was implemented, we used two models that simulate water quantity and quality to evaluate the combined field and riparian buffer system. The Agricultural Policy/Environmental eXtender (APEX) (Williams et al., 2008) was used to simulate of hydrology and water quality on the farm fields and the Riparian Ecosystem Management Model (REMM) was used to simulate attenuation of water, sediment, and nutrients in the riparian buffer between the farm field and the mangrove wetlands of Jobos Bay. Outputs from APEX were used to estimate edge of field loadings and as inputs to REMM. This paper describes calibration and validation of APEX and REMM using soils, hydrology and water quality field data. The models were calibrated using data from the first two years of the study (2008-2009) and then validated for the final year of the study (2010). After calibration and validation, the models were used to estimate water, sediment, and nutrient transport from the field, retention within the adjacent riparian buffer, and potential water, sediment, and nutrient delivery to the mangrove wetlands.

\section{Materials and methods}

\subsection{Model descriptions}

APEX is an extension of the widely tested Erosion-Productivity Impact Calculator (EPIC) model (Williams et al., 1984; Williams and Sharpley, 1989), an individual field scale model, originally used to estimate the effect of soil erosion on soil productivity (Gassman et al., 2005). APEX was developed to extend EPIC functions to include routing of nutrients, pesticides, water and sediment across landscapes (e.g. fields or subareas), through shallow groundwater, and into channel systems to a watershed outlet (Williams et al., 2008). APEX has been used to assess the effectiveness of conservation practices and is one of few models that are capable of simulating the routing of chemical pollutants and water at the field scale (Srivastava et al., 2007). Because APEX is able to consistently model various land management strategies at scales ranging from field to farm to small watersheds it was adopted by USDA NRCS for the CEAP national assessment (Wang et al., 2006).

REMM simulates carbon, nitrogen, phosphorus, pesticide, and sediment transport to surface waters via surface and subsurface flow through riparian buffers (Inamdar et al., 1999a,b; Lowrance et al., 2000). REMM was designed to represent a three-zone buffer system corresponding to specifications of the USDA-Forest Service and the USDA-NRCS (Welsch, 1991; USDA-NRCS, 1995; Inamdar et al., 1999a,b; Lowrance et al., 2000). In the three zone buffer, Zone 1 is the area nearest the stream or waterbody and Zones 2 and 3 are upslope from Zone 1 with Zone 3 adjacent to the field or source area. In REMM, the soil in each zone is characterized in three layers by which the lateral and vertical movement of water and associated dissolved chemicals are simulated. The uppermost soil layer is covered by a litter layer which interacts with surface runoff. More detail on REMM can be found in Inamdar et al. (1999a,b), Lowrance et al. (2000), and Altier et al. (2002).

\subsection{Study site}

The study was conducted in the Central Aguirre subwatershed of the Jobos Bay on the south coast of Puerto Rico $\left(17^{\circ} 56^{\prime} 36^{\prime \prime} \mathrm{N}\right.$, $\left.66^{\circ} 13^{\prime} 45^{\prime \prime} \mathrm{W}\right), 6 \mathrm{~km}$ southeast of the Municipality of Salinas. The study site includes a 108 ha silage production farm leased by a farmer/operator from the Puerto Rico Land Authority and the adjacent riparian buffer managed by the Puerto Rico Department of Natural Resources as part of the Jobos NERR (Fig. 1). The climate is tropical semiarid with a mean annual precipitation of $991 \mathrm{~mm}$ for the 30 year period (1971-2000) and a mean annual temperature of $26^{\circ} \mathrm{C}$, with a maximum of $28.6^{\circ} \mathrm{C}$ in August and a minimum of $22.4^{\circ} \mathrm{C}$ in January (NCDC, 2010). Seasons are defined as dry (November-May) and wet (June-October) which corresponds to the Atlantic hurricane season.

The aquifer underlying the study area is the South Coast Aquifer that is contained within alluvial deposits on the broad coastal plain that extends from Patillas westward to Ponce in southern Puerto Rico (Kuniansky and Rodriguez, 2010; USGS, 2011). The alluvium was deposited mostly in a number of coalescing fan-deltas that built seaward from the mouths of major streams. In the study area near Salinas, the alluvium ranges in thickness from about $30 \mathrm{~m}$ to more than $300 \mathrm{~m}$ near the coast. Ground water in these deposits generally is unconfined, except in areas near the coast where silt or clay beds create locally confined conditions. The water table generally slopes southward from the foothills of the island central cordillera to the Caribbean Sea. Near the coast, this aquifer is divided by a clay confining layer (1-20 m thick) which separates the aquifer into a lower confined portion and an upper unconfined portion. Our studies focused on the upper unconfined surficial aquifer.

The two dominant agricultural soils at the study site were Vertisols classified in the Cartagena and Ponceña Series. Cartagena clay soils are very deep and somewhat poorly drained and Ponceña clay soils are moderately well drained (SSURGO, 2010). Both soils were formed in clayey sediments weathered from volcanic rocks and limestone on the semiarid coastal plains of southern Puerto Rico. The Cartagena soils are on the low lying areas and are sodium enriched, while the Ponceña soils are on higher lying areas. The dominant hydrological soil group for both the Ponceña and Cartagena soils is type $\mathrm{D}$.

Management records used to build the database for APEX were obtained directly from the farm managers. The farm had been under center pivot irrigation for about 20 years, including the first two years of this study (2008-2009). In the final year of the study (2010), the center pivot irrigation was inoperable and crops were not grown. The field was divided into four quadrants (Fig. 1). Each quadrant was managed differently, however all were disk tilled once per year in October, and at least two of the four quadrants were simultaneously cropped at any time during 2008 and 2009 (Table 1). Multiple crops of corn (Zea mays L.) and/or sorghum (Sorghum bicolor L.) were grown in each subarea in 2008 and 2009 (Table 1). Because each quadrant was managed differently, each was considered a sub-watershed in APEX and will be referred to as subareas 1 through 4 (Fig. 1). Each subarea had multiple pesticide, fertilizer and irrigation management operations for each planting. During the 2008-2009 calibration period, the annual $\mathrm{N}$ application rate ranged from 0 to $150 \mathrm{~kg} \mathrm{ha}^{-1}$ for each subarea with an annual average of $73 \mathrm{~kg} \mathrm{ha}^{-1}$ across the four subareas. Fertilizer was applied multiple times for each crop planted in each subarea. In 2010, the irrigation system was not working thus planting did not occur and there were no fertilizer applications to any of the subareas.

The 16 ha riparian buffer is situated in the tidal flats area which lies directly between the upland field and the mangrove wetland 


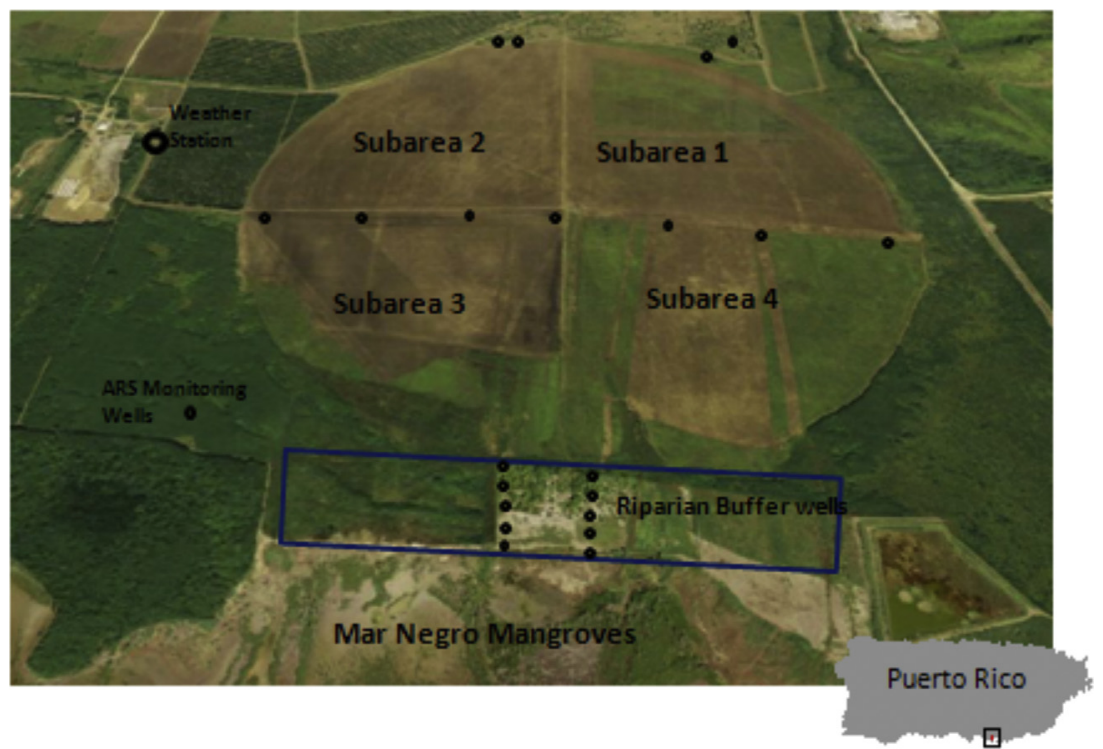

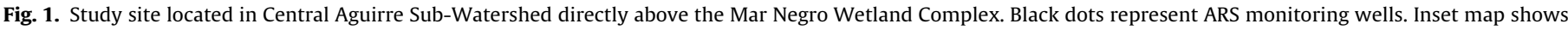
location on the south coast of Puerto Rico. Image U.S. Geological Survey. Copyright Google Earth.

(Fig. 1). The riparian soils were classified as tidal flats (Tf) which consist of low lying areas, slightly above sea level, that are affected by seawater during storm tides. The soil material has high salinity and varies widely in texture. The riparian buffer was $156 \mathrm{~m}$ wide from the upland field to the mangroves (perpendicular to the mangroves) and $1039 \mathrm{~m}$ long (the dimension along the mangroves). The REMM Zone 1 width was $77 \mathrm{~m}$ and Zone 2 was $40 \mathrm{~m}$. Vegetation in both zones were tropical trees and shrubs, mostly leadtree (Leucaena leucocephala deWit.), devil's horsewhip (Achyranthes aspera), and Egyptian river hemp (Sesbania sesban L. Merr.). REMM Zone 3 , which was furthest away from the mangroves is $40 \mathrm{~m}$ wide and was vegetated with perennial grasses, primarily Guinea grass

Table 1

Crop planting and harvesting for each of the 4 subareas at the Silage Farm.

\begin{tabular}{lllll}
\hline Year & Subarea ID & Crop & Plant & Harvest \\
\hline 2008 & SA1 & Corn & 5-February & 26-April \\
2008 & SA1 & Corn & 29-April & 15-July \\
2008 & SA1 & Corn & 30-October & 19-January \\
2009 & SA1 & Cowpea & 8-April & 15-September \\
2010 & SA1 & Fallow & & \\
2008 & SA2 & Corn & 18-January & 20-May \\
2008 & SA2 & Sorghum & 21-May & 15-August \\
2008 & SA2 & Corn & 16-December & 2-February \\
2009 & SA2 & Corn & 1-June & 31-August \\
2009 & SA2 & Sorghum & 14-September & 7-December \\
2010 & SA2 & Fallow & & \\
2008 & SA3 & Sorghum & 19-March & 23-July \\
2008 & SA3 & Sorghum & 26-July & 25-September \\
2008 & SA3 & Sorghum & 27-September & 7-December \\
2009 & SA3 & Sorghum & 4-February & 24-March \\
2009 & SA3 & Sorghum & 26-June & 31-August \\
2009 & SA3 & Sorghum & 26-October & 7-December \\
2010 & SA3 & Fallow & & \\
2008 & SA4 & Sorghum & 18-January & 26-April \\
2008 & SA4 & Sorghum & 29-April & 30-June \\
2008 & SA4 & Sorghum & 4-November & 4-January \\
2009 & SA4 & Sorghum & 18-January & 20-May \\
2009 & SA4 & Sorghum & 17-July & 7-October \\
2009 & SA4 & Sorghum & 12-October & 7-December \\
2010 & SA4 & Fallow & & \\
\hline & & &
\end{tabular}

\footnotetext{
a Cowpea was tilled under on this date.
}

(Megathyrsus maximus (Jacq.) B.K. Simon and S.W.L. Jacobs), Signal grass (Urochloa distachya (L.), T.K. Nguyen), and Johnson grass (Sorgum halepense (L.) Pers.). The slope length of the 108 ha contributing field was $1039 \mathrm{~m}$, yielding a field to riparian area ratio of approximately $7: 1$. The ground surface slope from the upland field to the mangrove wetlands was $1 \%$.

\subsection{Site data}

Site data collected included weather, soil chemical and physical properties, topographic information, and water table depths for the upland field and the riparian buffer. Weather measurements (minimum and maximum temperature, daily total solar radiation, precipitation, relative humidity, and wind speed) were obtained from a HOBO (Onset Computer Corp., Bourne, MA) weather station that was installed in 2008 (Fig. 1). Onset Smart Sensors were connected to an Onset Hobo Event logger. When data from the site were missing, weather data were used from the Jobos Bay NERR (NERRS, 2009) weather station which is $2 \mathrm{~km}$ away from the study location.

Soil property data by layer for the two dominant soil series in each subarea were used for APEX and REMM database development (Tables 2 and 3, respectively). Soil layer depth, $\mathrm{pH}$, percent organic carbon, bulk density, field capacity, wilting point, percentage sand and silt, saturated conductivity, cation exchange capacity, sum of bases, calcium carbonate content, and soil albedo were measured at the study site by USDA-NRCS in 2007 (NCSS, 2009). A separate set of soil samples were collected from the farm field for physical property measurements in 2009. Minimally disturbed cores were collected from the top $7.6 \mathrm{~cm}$ of soil on each plot using an Uhland impact type soil sampler (Blake and Hartge, 1986). Saturated hydraulic conductivity $\left(K_{\mathrm{s}}\right)$, soil moisture retention expressed as volumetric moisture content, and bulk density were measured on the cores. The soil cores were saturated from the bottom for determination of $K_{\mathrm{s}}$ using the constant head method (Klute and Dirksen, 1986). Rooting depth in the fields and riparian buffer were estimated from observation of fresh soil cores in the field. Saturated hydraulic conductivities of all soil layers in the riparian buffer and of soil layers 2 and 3 in the field were estimated with the ROSETTA model (Schaap et al., 2001) using measurements of percentages 
Table 2

Soil properties by layer for Cartagena and Ponceña soils.

\begin{tabular}{|c|c|c|c|c|c|c|c|c|c|}
\hline Layer & Soil series & $\begin{array}{l}\text { Layer depth } \\
(\mathrm{cm})\end{array}$ & $\begin{array}{l}\text { Bulk density } \\
\left(\mathrm{g} \mathrm{cm}^{-3}\right)\end{array}$ & $\begin{array}{l}\text { Wilting point } \\
\left(\mathrm{m} \mathrm{m}^{-1}\right)\end{array}$ & $\begin{array}{l}\text { Field capacity } \\
\left(\mathrm{m} \mathrm{m}^{-1}\right)\end{array}$ & Sand (\%) & Silt (\%) & $\mathrm{pH}$ & $\begin{array}{l}\text { Organic carbon } \\
\text { (\%) }\end{array}$ \\
\hline 1 & Cartagena & $0-23$ & 2.00 & 0.18 & 0.26 & 28.3 & 27.8 & 7.7 & 0.82 \\
\hline 2 & Cartagena & $24-79$ & 1.99 & 0.16 & 0.22 & 28.6 & 33.1 & 7.8 & 0.27 \\
\hline 3 & Cartagena & $80-180$ & 2.05 & 0.16 & 0.22 & 25.1 & 32.6 & 7.8 & 0.02 \\
\hline 1 & Poncena & $0-40$ & 1.94 & 0.15 & 0.28 & 20.7 & 31.6 & 7.9 & 0.81 \\
\hline 2 & Poncena & 41-137 & 1.95 & 0.18 & 0.27 & 20.35 & 32.1 & 7.9 & 0.22 \\
\hline 3 & Poncena & $138-180$ & 1.98 & 0.18 & 0.24 & 22.75 & 36.6 & 7.9 & 0.03 \\
\hline
\end{tabular}

of sand, silt and clay; bulk density; and water retention at 33 and $1500 \mathrm{kPa}$ as input parameters.

Groundwater data were collected from March 2008 to December 31, 2010 to evaluate hydrologic processes in the landscape and calibrate and validate the models. Thirteen monitoring wells were installed on or adjacent to the upland field and 10 wells in the riparian buffer in 2008 (Fig. 1). Two wells installed north of the upland field and two, located south of the upland field, that were already in place when the study began were instrumented with pressure transducers and HOBO real time data loggers to monitor water table depth. Tape-down measurements were made in all of the remaining wells monthly. Groundwater samples were collected monthly for water quality analysis after tape down. Wells were purged with a submersible pump and then sample water was collected with a bailer from the water that flowed back into the well. Samples were stored on ice in the field and then frozen for transport to the USDA-ARS laboratory in Tifton, GA. Nitrate plus nitrite $\mathrm{N}$ was determined using the cadmium reduction technique on a Lachat 8000 flow injection analyzer. The method detection limit was $0.02 \mathrm{mg} \mathrm{NO}_{3}-\mathrm{N} \mathrm{L}^{-1}$.

Monitoring wells in the upland field were located along the east-west axis of the field (Fig. 1). The water table depths used to calibrate and validate both APEX and REMM were observed daily values for the middle of the subarea. We were interested in evaluating the riparian buffer as a whole instead of three separate zones; therefore we compared the REMM average water table depths for all three zones versus the interpolated water table depths for both calibration and validation. Shallow groundwater nitrate data from wells in the riparian buffer were compared to REMM simulated concentrations for validation.

\subsection{Model input data}

APEX model inputs included daily weather, soil properties by layer, land use, planting and harvesting dates, tillage type and dates, and fertilizer applications. The daily weather variables necessary for model simulation were precipitation, minimum and maximum air temperature, and solar radiation. The Hargreaves method (Hargreaves and Samani, 1985) was used to calculate potential evapotranspiration for this particular study and was also used for the national CEAP study. The APEX field operation schedule was configured based on actual management occurring at the study site (Table 1).

REMM took upland outputs, which in this case were generated by APEX, and calculated loadings of water, nutrients, sediment, and carbon based on actual area of the three zones of the buffer system. Daily field outputs generated from APEX and used for REMM inputs included surface runoff; subsurface flow; sediment yield; and N, $P$, and $C$ in surface runoff, subsurface flow, and sediment. Other REMM inputs included daily weather (same as for APEX), soil, plant, and litter properties by layer, and vegetation type by zone. Initial conditions for soil include physical and hydrologic properties, and initial carbon and nutrient pools.

\subsection{Simulation methodology and model performance}

APEX and REMM were both calibrated for 2008 and 2009 and then run for the validation period, 2010, using the calibrated models. Because hydrologic data for surface runoff were not available, calibration and validation were done with groundwater data using depth to water table in the field and riparian buffer and groundwater nitrate in the riparian buffer.

Water table input parameters for APEX are presented in Table 4. Each subarea was assumed to be homogenous with an average slope of $1 \%$ and a single soil type (Table 4 ). APEX calibration was performed using the observed daily water table depths for March 2008-December 2009 by manually adjusting APEX parameters 87 , 88 , and 89 on a trial-and-error basis (Table 4). Parameter 87 (P87), a water table recession coefficient, limits the rate at which the water table recedes. The range for this coefficient is $0.001-1.0$, where smaller values slow the water table recession. Parameter 88 (P88) limits the daily water table movement and is a fraction of the difference between the current day water table depth (WTBL) and the minimum (WTMN) or maximum (WTMX) water table depth. The range for this coefficient is 0.001-1.0. Parameter 89 (P89) adjusts the water table recession exponent and the range is $0.1-0.9$. The antecedent period (rainfall) is user defined and ranges from 5 to 30 days. APEX simulated water table depth for each subarea but

Table 3

Soil properties by layer for riparian zone soils.

\begin{tabular}{|c|c|c|c|c|c|c|c|c|c|}
\hline Zone & & Depth $(\mathrm{cm})$ & $\begin{array}{l}\text { Bulk density } \\
\left(\mathrm{g} \mathrm{cm}^{3}\right)\end{array}$ & $\begin{array}{l}\text { Wilting point } \\
\left(\mathrm{m} \mathrm{m}^{-1}\right)\end{array}$ & $\begin{array}{l}\text { Field capacity } \\
\left(\mathrm{m} \mathrm{m}^{-1}\right)\end{array}$ & Sand (\%) & Silt (\%) & $\mathrm{pH}$ & $\begin{array}{l}\text { Organic } \\
\text { carbon (\%) }\end{array}$ \\
\hline \multirow[t]{3}{*}{1} & Layer 1 & $0-20$ & 1.50 & 0.24 & 0.37 & 32.60 & 27.40 & 8.17 & 2.20 \\
\hline & Layer 2 & $20-220$ & 1.40 & 0.28 & 0.39 & 27.60 & 25.40 & 8.77 & 1.00 \\
\hline & Layer 3 & $220-300$ & 1.40 & 0.28 & 0.39 & 24.60 & 27.40 & 8.53 & 1.00 \\
\hline \multirow[t]{3}{*}{2} & Layer 1 & $0-20$ & 1.40 & 0.22 & 0.35 & 46.60 & 21.40 & 7.94 & 2.21 \\
\hline & Layer 2 & $20-220$ & 1.40 & 0.28 & 0.37 & 31.60 & 23.40 & 8.29 & 1.31 \\
\hline & Layer 3 & $220-300$ & 1.40 & 0.28 & 0.39 & 31.60 & 22.40 & 8.20 & 1.16 \\
\hline \multirow[t]{3}{*}{3} & Layer 1 & 0-20 & 1.60 & 0.22 & 0.35 & 31.60 & 28.40 & 8.44 & 2.69 \\
\hline & Layer 2 & $20-220$ & 1.40 & 0.28 & 0.39 & 27.60 & 25.40 & 8.66 & 1.65 \\
\hline & Layer 3 & $220--300$ & 1.40 & 0.28 & 0.39 & 28.60 & 25.40 & 8.63 & 1.27 \\
\hline
\end{tabular}


Table 4

Water table and soil input parameters in APEX. WTBL is the current day water table depth, WTMN is the minimum water table depth, and WTMX is the maximum water table depth. Parameter 87,88 , and 89 are APEX parameters that limit daily water table movements and are explained more fully in the text.

\begin{tabular}{lllll}
\hline & Subarea 1 & Subarea 2 & Subarea 3 & Subarea 4 \\
\hline Subarea size (ha) & 27 & 27 & 27 & 27 \\
Antecedent rainfall (days) & 15 & 15 & 15 & 15 \\
WTMN (m) & 0.00 & 0.00 & 0.00 & 0.00 \\
WTMX (m) & 5.50 & 7.50 & 4.00 & 5.50 \\
WTBL (m) & 3.01 & 3.43 & 2.07 & 2.43 \\
Upper slope (\%) & 1.00 & 1.00 & 1.00 & 1.00 \\
Hydrology group & $\mathrm{D}$ & $\mathrm{D}$ & $\mathrm{D}$ & $\mathrm{D}$ \\
P87 & & & 0.012 & \\
P88 & & & 0.020 & \\
P89 & & & 0.900 & \\
\hline
\end{tabular}

a P87, P88, and P89 parameters are the same for all subareas in APEX.

parameters to calibrate the water table depth were common to all four subareas so adjustments made to one subarea affected all subarea water table depth calibrations. After identification of a set of optimum values, the calibrated model was then continuously run for the validation period (2010) using these parameter values (Table 4).

Water table depths in REMM are directly influenced by rooting depth, soil moisture, saturated hydraulic conductivity, porosity, pore size distribution, and the bubbling pressure head for soil
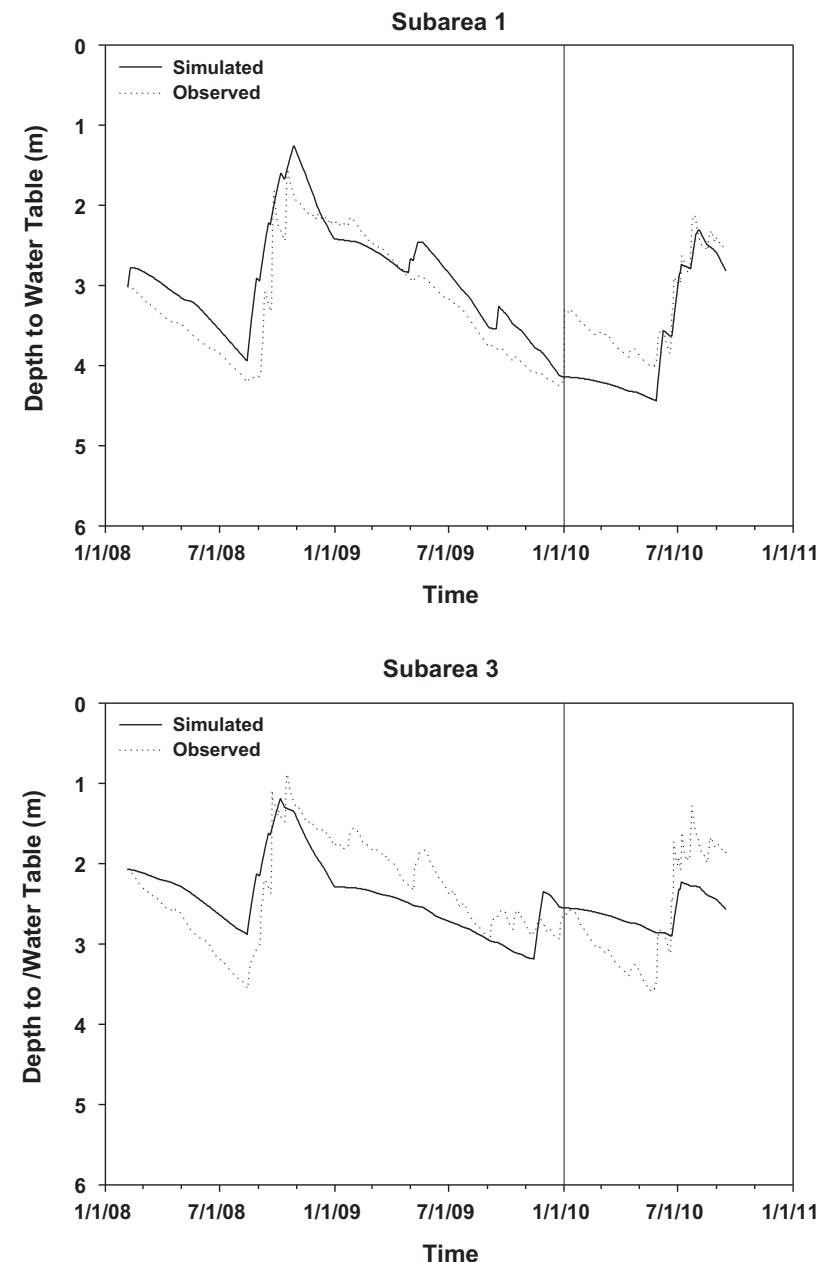

(Altier et al., 2002). Parameter values estimated using the ROSETTA model were field capacity, saturated hydraulic conductivity, and porosity and were not changed during the calibration process. Values for pore size distribution, and bubbling pressure were estimated using textural classification (Ritchie, 1972; USDA-SCS, 1984; Altier et al., 2002) and were adjusted within literature values during calibration. Available moisture in soil layers is partitioned among roots of each plant type and water is taken up from soil layers from the surface downward (Altier et al., 2002). If roots are not present in a layer, REMM does not allow water uptake from that layer. The maximum rooting depth for all three zones was set at $150 \mathrm{~cm}$, which is within the range of rooting depths for the plant species evaluated and was not adjusted during the calibration period; however soil layer depths (layers 2 and 3 ) for each zone were adjusted to keep the roots out of soil layer 3 and thus maintain a permanent water table in soil layer 3, as observed in the field.

Simulated and observed water table depths were compared using mean, standard deviation (SD), coefficient of determination $\left(R^{2}\right)$, Nash-Sutcliffe efficiency (NSE) (Nash and Sutclifee, 1970), percent bias (PBIAS), and root mean square error (RMSE) for both the calibration and validation periods. The PBIAS is a simple goodnessof -fit criterion. For a perfect model, PBIAS is equal to zero, and the smaller the PBIAS, the better the model performance. The RMSE is used to measure differences between predicted and observed values. It is a good measure of model precision. The NSE coefficient is a common measurement used to evaluate hydrologic model performance. Values range from $-\infty$ to one, where a value of one indicates
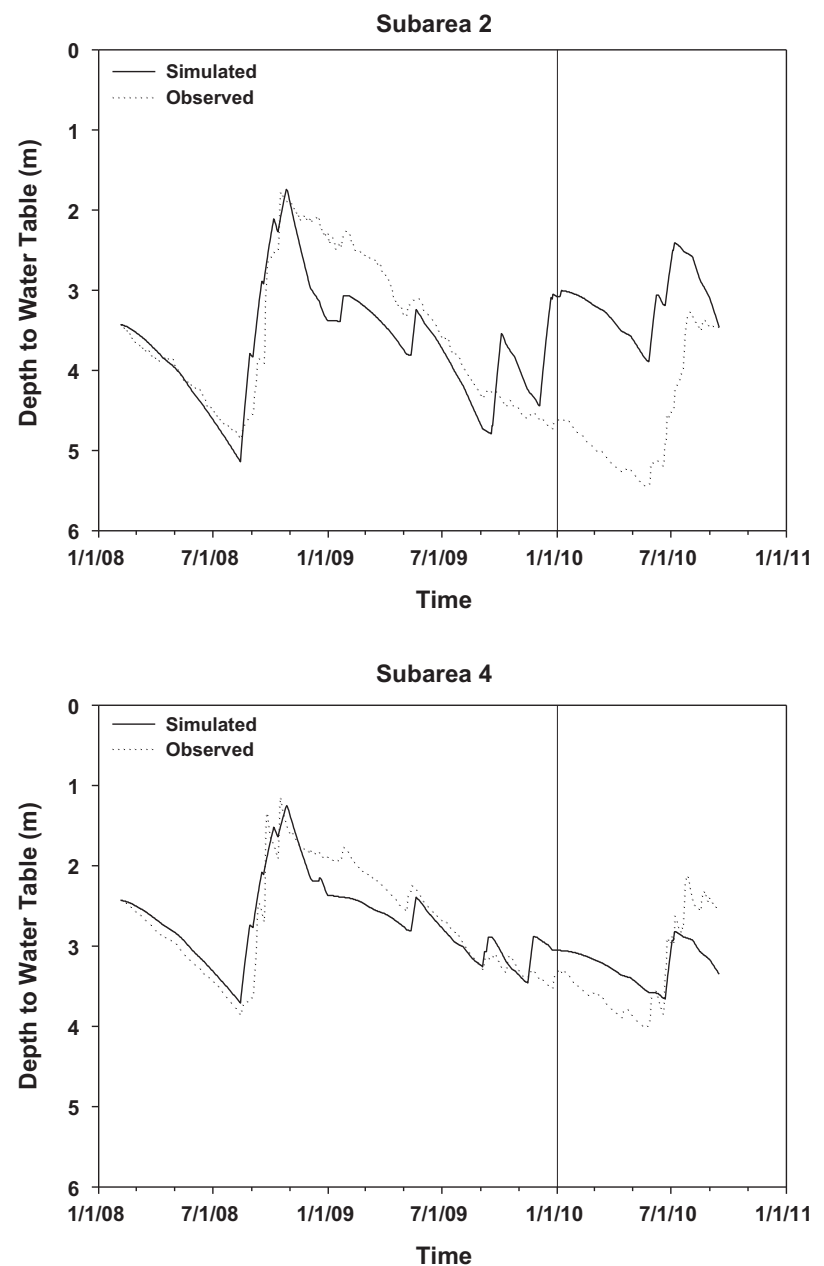

Fig. 2. Observed and APEX simulated water table depths for the upland field at the Silage Farm for each of the subareas. 
Table 5

Observed versus simulated daily water table depths ( $\mathrm{m}$ ) statistics for the calibration (2008-2009) and validation (2010) periods.

\begin{tabular}{|c|c|c|c|c|c|c|c|c|}
\hline \multirow[t]{2}{*}{ Area } & \multicolumn{2}{|c|}{ Measured } & \multicolumn{2}{|c|}{ Simulated } & \multirow[t]{2}{*}{$R^{2}$} & \multirow[t]{2}{*}{ NSE } & \multirow[t]{2}{*}{ PBIAS } & \multirow[t]{2}{*}{ RMSE } \\
\hline & Mean & Std & Mean & Std & & & & \\
\hline \multicolumn{9}{|l|}{ Subarea 1} \\
\hline Calibration & 3.2 & 0.72 & 2.9 & 0.65 & 0.86 & 0.72 & -8.5 & 0.38 \\
\hline Validation & 4.1 & 0.57 & 3.8 & 0.77 & 0.85 & 0.33 & -8.0 & 0.47 \\
\hline \multicolumn{9}{|l|}{ Subarea 2} \\
\hline Calibration & 3.6 & 0.89 & 3.7 & 0.71 & 0.67 & 0.65 & 3.4 & 0.53 \\
\hline Validation & 4.6 & 0.71 & 3.1 & 0.37 & 0.46 & -3.77 & -31.6 & 1.55 \\
\hline \multicolumn{9}{|l|}{ Subarea 3} \\
\hline Calibration & 2.3 & 0.59 & 2.4 & 0.44 & 0.47 & 0.45 & 2.9 & 0.44 \\
\hline Validation & 2.6 & 0.66 & 2.6 & 0.19 & 0.67 & 0.38 & -2.0 & 0.51 \\
\hline \multicolumn{9}{|l|}{ Subarea 4} \\
\hline Calibration & 2.7 & 0.65 & 2.7 & 0.51 & 0.82 & 0.80 & 0.5 & 0.29 \\
\hline Validation & 3.3 & 0.57 & 3.2 & 0.22 & 0.41 & 0.33 & -2.3 & 0.46 \\
\hline \multicolumn{9}{|c|}{ Riparian zone } \\
\hline Calibration & 1.5 & 0.48 & 1.6 & 0.64 & 0.69 & 0.41 & 4.3 & 0.37 \\
\hline Validation & 1.5 & 0.52 & 1.4 & 0.72 & 0.95 & 0.7 & -3.7 & 0.29 \\
\hline
\end{tabular}

good model performance and values less than zero indicate that the average of the observed data is a better predictor than the model. Mean $\mathrm{NO}_{3}-\mathrm{N}$ concentrations in the riparian wells were compared to the water table calibrated REMM simulated values for the entire study period (2008-2010) for each zone of the buffer with no further calibration of REMM for groundwater nitrate. Because the data were not normally distributed we used nonparametric tests (Mann-Whitney U Statistic and Kruskal-Wallis One Way ANOVA on Ranks) for differences (SigmaPlot, 2012). We calculated percent reduction for the entire riparian buffer for the entire study period. Percent reduction was calculated as ((input - output)/input)* 100 .

\section{Results and discussion}

\subsection{Calibration and validation}

Summary statistics for observed and APEX and REMM simulated water table depths are presented in Table 5. The average simulated depths to water table for each subarea were within $\pm 7 \%$ of the corresponding observed value for both the calibration and validation periods with the exception of subarea 2 for the validation period. The $R^{2}$ values ranged from 0.41 to 0.95 and NSE values from 0.33 to 0.80 , except subarea 2 which was -3.77 . The PBIAS were within $\pm 9 \%$ during both the calibration and validation periods with the exception of subarea 2 which was $-31.6 \%$. The RMSE for both the calibration and validation periods was low suggesting that water table depths were similar. These performance metrics indicated that APEX and REMM were able to reasonably simulate daily water table depths.

Daily time series of for observed and APEX-simulated water table depths are shown in Fig. 2. The graphical comparisons suggest that APEX reasonably tracked trends during the calibration period, however, consistently over predicted the depths to the water table during the dry season (greater water table depths). APEX was not as efficient during the validation period. Generally APEX performed better during the wet season (lesser water table depths) in comparison to the dry season and responded well to precipitation events. The fields were not cultivated during the validation period (2010) but there was vegetative cover due to substantial weed growth and volunteer sorghum re-growth. APEX under-predicted the depth to water table during this period, with the exception of subarea 1 , likely as a result of an underestimation of actual plant biomass and associated transpiration.

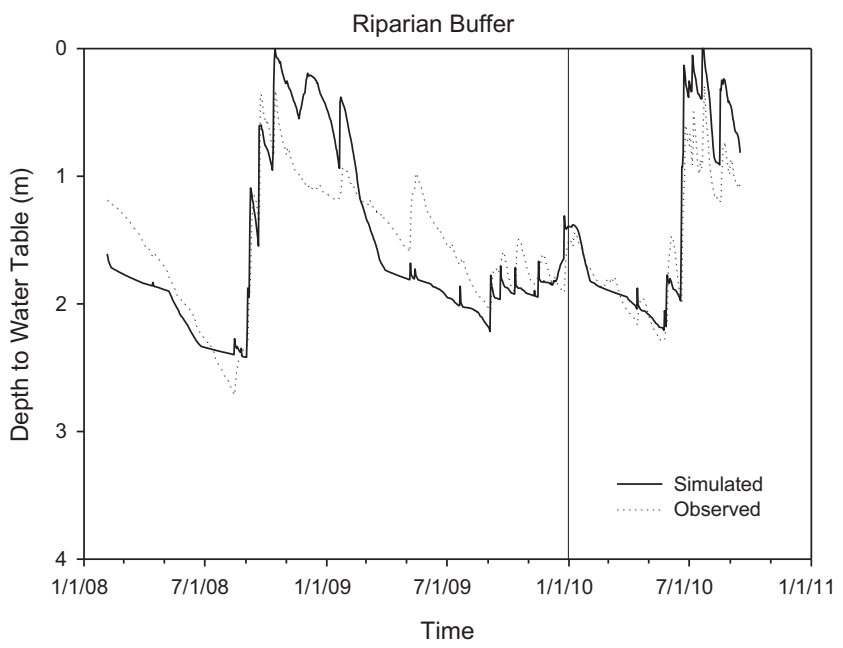

Fig. 3. Observed and REMM simulated water table depths for the riparian buffer zone at the Silage Farm.

Daily time series of water table depths for observed and REMM simulated values are shown in Fig. 3. There were periods during the validation when REMM either over predicted or under predicted the depths to the water table. As with APEX, REMM performed better during the wet season in comparison to the dry season and responded well to precipitation events. In contrast to the APEX simulations, there were no vegetation changes in the riparian buffer during the validation period (2010). REMM was able to track the trends in water table depths fairly well during this period.

Observed and REMM simulated monthly groundwater nitrate$\mathrm{N}$ concentrations are shown in Table 6 for the three REMM zones of the buffer. There was no significant difference among the observed and simulated for Zone 3 of the buffer. The observed monthly nitrate concentrations ranged from 0 to $1.48 \mathrm{mg} \mathrm{NO}_{3}-\mathrm{N} \mathrm{L}^{-1}$ with a mean of $0.13 \mathrm{mg} \mathrm{NO}_{3}-\mathrm{N} \mathrm{L}^{-1}$ and standard deviation of $0.23 \mathrm{mg}$ $\mathrm{NO}_{3}-\mathrm{N} \mathrm{L}^{-1}$. The REMM simulated monthly nitrate concentrations ranged from 0 to $1.49 \mathrm{mg} \mathrm{NO}_{3}-\mathrm{N} \mathrm{L}^{-1}$ with a mean of $0.10 \mathrm{mg} \mathrm{NO}_{3}-$ $\mathrm{N} \mathrm{L}^{-1}$ and standard deviation of $0.18 \mathrm{mg} \mathrm{NO}_{3}-\mathrm{N} \mathrm{L}^{-1}$. The observed percent reduction in concentration between zones 3 and 1 was $94 \%$ and the simulated percent reduction was $100 \%$. REMM overestimated nitrate removal in Zone 2 and 1 of the buffer but observed 
Table 6

Monthly averaged (2008-2010) observed and REMM simulated groundwater nitrate concentrations by zone.

\begin{tabular}{lllll}
\hline & \multicolumn{1}{l}{ Observed } & SD & REMM & SD \\
\cline { 2 - 5 } & $\mathrm{NO}_{3}-\mathrm{N}\left(\mathrm{mg} \mathrm{L}^{-1}\right)$ & & \\
\hline Zone 3 (adjacent to silage & $0.33^{\mathrm{b}}$ & 0.30 & 0.54 & 0.53 \\
$\quad$ field) & & & & \\
Zone 2 & $0.02^{\mathrm{a}}$ & 0.07 & 0.00 & 0.00 \\
Zone 1 (adjacent to Mar & $0.02^{\mathrm{a}}$ & 0.03 & 0.00 & 0.00 \\
$\quad$ Negro Wetland) & & & & \\
\hline
\end{tabular}

a Observed versus simulated nitrate concentrations were significantly different based on the Mann-Whitney test. The detection limit for the methodology is $0.02 \mathrm{mg}$ $\mathrm{NO}_{3}-\mathrm{NL}^{-1}$.

b Observed versus simulated nitrate concentrations were not significantly different based on the Mann-Whitney test.

concentrations were very low and generally below method detection limits.

\subsection{Apex simulated field outputs}

Mean annual water, sediment, and nutrient data from APEX and REMM simulations for the three year period are shown in Table 7. Annual rainfall was $1059 \mathrm{~mm}$ in $2008,670 \mathrm{~mm}$ in 2009, and $1400 \mathrm{~mm}$ in 2010. Annual irrigation was $553 \mathrm{~mm}$ in 2008, $1270 \mathrm{~mm}$ in 2009, and zero in 2010. APEX simulated discharge of water was $14 \%$ of total rainfall and irrigation. Surface runoff was greatest during 2008, with $443 \mathrm{~mm} \mathrm{ha}^{-1}$, representing $80 \%$ of total surface runoff for the three years. This was due to a series of tropical cyclones that impacted the site in August-October 2008. Tropical Storm Faye (August 15, 2008), Hurricane Kyle (September 21-25, 2008), and Hurricane Omar (October 12-15, 2008) caused $32 \mathrm{~mm}$, $364 \mathrm{~mm}$, and $25 \mathrm{~mm}$ of runoff, respectively. Surface runoff was $81 \mathrm{~mm} \mathrm{ha}^{-1}$ in 2009 and $31 \mathrm{~mm} \mathrm{ha}^{-1}$ in 2010 . On days when the fields were irrigated, $13 \mathrm{~mm} \mathrm{ha}^{-1}$ of subsurface flow and $4 \mathrm{~mm} \mathrm{ha}^{-1}$ of surface runoff were generated. APEX simulated subsurface flow was $40 \mathrm{~mm} \mathrm{ha}^{-1}$ in $2008,33 \mathrm{~mm} \mathrm{ha}^{-1}$ in 2009 , and $54 \mathrm{~mm} \mathrm{ha}^{-1}$ in 2010. The greatest amount of subsurface flow $\left(54 \mathrm{~mm} \mathrm{ha}^{-1}\right)$ was generated during 2010 when rainfall events were more evenly distributed and there was no crops grown (Fig. 4a).

APEX simulated sediment transport was $28 \mathrm{Mg} \mathrm{ha}^{-1}$ in 2008 , $0.7 \mathrm{Mgha}^{-1}$ in 2009 , and $0.01 \mathrm{Mgha}^{-1}$ in 2010 . Most of the sediment transported in $2008\left(25.7 \mathrm{tha}^{-1}\right)$ was associated with Hurricane Kyle. This was $93 \%$ of total sediment transported from

Table 7

Mean annual simulated transport of water, sediments, and nutrients from APEX and REMM. Percent reduction is calculated as ((input - output)/input)*100.

\begin{tabular}{|c|c|c|c|}
\hline Parameter & APEX & REMM & \% Reduction \\
\hline Rainfall & 3129 & 3129 & \\
\hline Irrigation & 1873 & $30^{\mathrm{a}}$ & \\
\hline Total water & 227 & 190 & 16 \\
\hline Surface runoff $\left(\mathrm{mm} \mathrm{ha}^{-1} \mathrm{y}^{-1}\right)$ & 185 & 179 & 3 \\
\hline Subsurface flow $\left(\mathrm{mm} \mathrm{ha}^{-1} \mathrm{y}^{-1}\right)$ & 42 & 0.3 & 99 \\
\hline Sediment yield ( $\left.\mathrm{Mg} \mathrm{ha}^{-1} \mathrm{y}^{-1}\right)$ & 10 & 7 & 30 \\
\hline \multicolumn{4}{|l|}{ Nitrogen } \\
\hline Total load $\left(\mathrm{kg} \mathrm{ha}^{-1} \mathrm{y}^{-1}\right)$ & 195 & 135 & 31 \\
\hline Dissolved surface runoff- $\mathrm{N}\left(\mathrm{kg} \mathrm{ha}^{-1} \mathrm{y}^{-1}\right)$ & 27 & 8 & 70 \\
\hline Dissolved subsurface flow-N ( $\left.\mathrm{kg} \mathrm{ha}^{-1} \mathrm{y}^{-1}\right)$ & 0.7 & 0 & 100 \\
\hline Sediment- $\mathrm{N}\left(\mathrm{kg} \mathrm{ha}^{-1} \mathrm{y}^{-1}\right)$ & 168 & 126 & 25 \\
\hline \multicolumn{4}{|l|}{ Phosphorus } \\
\hline Total load $\left(\mathrm{kg} \mathrm{ha}^{-1} \mathrm{y}^{-1}\right)$ & 7 & 5 & 29 \\
\hline Dissolved surface runoff-P $\left(\mathrm{kg} \mathrm{ha}^{-1} \mathrm{y}^{-1}\right)$ & 1 & 0.3 & 67 \\
\hline Sediment-P $\left(\mathrm{kg} \mathrm{ha}^{-1} \mathrm{y}^{-1}\right)$ & 6 & 4 & 33 \\
\hline
\end{tabular}

\footnotetext{
a Volume of runoff from REMM on days when silage field was irrigated.
}

APEX during that year (Fig. 4b). The total mass of sediment transported on irrigation days was $0.23 \mathrm{tha}^{-1}$, which was less than $1 \%$ of total sediment transported during the 3-year study period.

Approximately $86 \%$ of the $\mathrm{N}$ output was sediment bound with 66\% generated during Hurricane Kyle in 2008 (Fig. 4d). The remaining $\mathrm{N}$ output was transported as inorganic $\mathrm{N}$ in surface runoff and was more evenly distributed during the study period (Fig. 4c). The total mass of $\mathrm{N}$ transported on days which irrigation occurred was $7.8 \mathrm{~kg} \mathrm{Nha}^{-1}$, for the 3 -year period, $1 \%$ of total $\mathrm{N}$ transported. Most of the $\mathrm{N}$ transported on irrigation days was $\mathrm{NH}_{4}$ $\mathrm{N}$ in surface runoff. The simulated total $\mathrm{N}$ output data generated by APEX (Table 6) was greater than the range of $\mathrm{N}$ outputs in other watersheds (Lowrance et al., 1985, 2007), likely as a result of the tropical storms driving the system.

The simulated $\mathrm{P}$ transport was $19 \mathrm{~kg} \mathrm{Pha}^{-1}$ in $2008,1 \mathrm{~kg} \mathrm{Pha}^{-1}$ in 2009 , and less than $1 \mathrm{~kg} \mathrm{Pha}^{-1}$ in 2010 with $74 \%$ generated as a result of Hurricane Kyle (Fig. 4f). The majority of total P transport was in particulate form $\left(17 \mathrm{~kg} \mathrm{P} \mathrm{ha}^{-1}\right)$. Not including Hurricane Kyle, total P output was very small and constant for the 3-year period with a yearly average of $1.8 \mathrm{~kg} \mathrm{P} \mathrm{ha}^{-1}$. Total $\mathrm{P}$ transported on irrigation days was $0.25 \mathrm{~kg} \mathrm{Pha}^{-1}$, which was less than $1 \%$ of total $\mathrm{P}$ transported during the 3-year study. The simulated dissolved $\mathrm{P}$ transport was more evenly distributed (Fig. 4e).

\subsection{Remm simulated riparian outputs}

Simulated loadings transported to REMM from APEX were the daily volume of water, mass of sediment, and nitrogen and phosphorus in both surface runoff (dissolved and particulate) and subsurface flow. REMM simulated reductions of APEX simulated field outputs represent decreases of water, sediment, and nutrients reaching the mangrove wetlands.

REMM simulated surface runoff output was $425 \mathrm{~mm} \mathrm{ha}^{-1}$ in $2008,49 \mathrm{~mm} \mathrm{ha}^{-1}$ in 2009, and $63 \mathrm{~mm} \mathrm{ha}^{-1}$ in 2010. The overall reduction in water flow in the buffer for the 3-year study period was $16 \%$ (Table 7 ). REMM simulated an $8 \%$ reduction of surface runoff for Tropical Storm Faye but only a $1 \%$ reduction in runoff from Hurricane Kyle (Fig. 4a) due to the antecedent soil moisture conditions of the riparian buffer when these storms occurred and the intensity of the rainfall events. Up until Tropical Storm Faye, the surface runoff reduction in REMM was $100 \%$. A series of rain events occurring after Tropical Storm Faye, including Tropical Storm Omar produced little to no surface runoff entering the buffer. However, due to saturated conditions surface runoff was generated from the buffer and for these events there were increases in runoff from the buffer. Year 2009 was a dry year and REMM simulated daily surface runoff reductions ranged between $53 \%$ and $100 \%$ with the exception of one rainfall event that occurred on December 25, 2009 that had $66 \mathrm{~mm}$ of rain and only a $2 \%$ reduction of surface runoff. REMM simulated surface runoff suggests that the riparian buffer substantially reduced surface runoff, however, intense rainfall events such as tropical storms and hurricanes may overwhelm the buffer and deliver runoff from the riparian buffer to the mangrove wetlands. The flow from APEX generated as a result of irrigation was reduced by $77 \%$ in REMM.

REMM reduced subsurface flow by 99\% (Table 7). The large decrease in REMM subsurface flow was the result of low gradients and low hydraulic conductivities in the riparian buffer and high evapotranspiration in the tropical environment. Exfiltration (surface seepage) at the edge of the riparian buffer as generated in REMM was $124 \mathrm{~mm} \mathrm{ha}^{-1}$ which was $98 \%$ of the subsurface flow that was generated from APEX. Exfiltration leaving Zone 1 was $32 \mathrm{~mm} \mathrm{ha}^{-1}$, a $74 \%$ decrease from the edge of the buffer. The difference in exfiltration at the edge of the buffer and the exfiltrated 

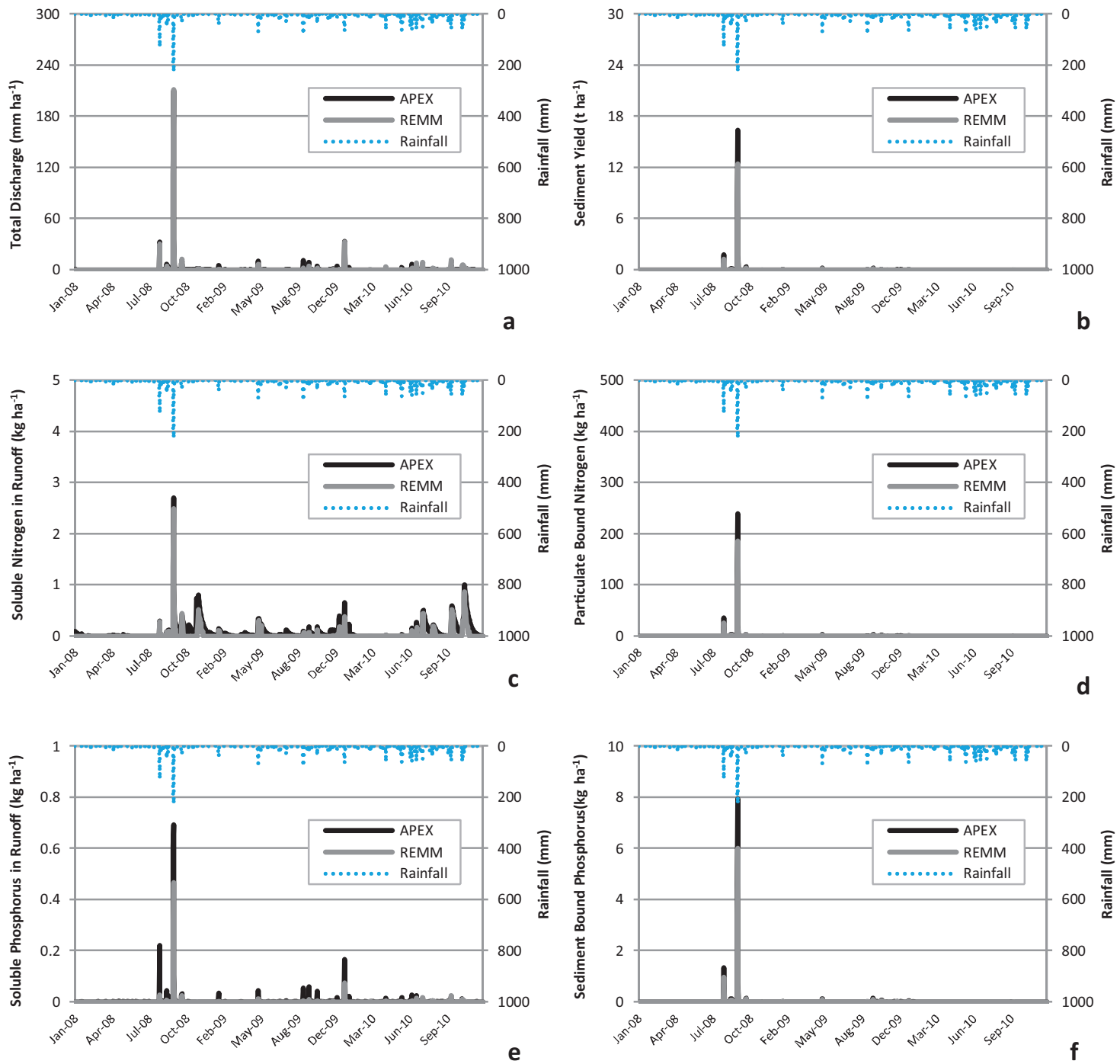

Fig. 4. Total volume of discharge, mass of sediments, and nutrients transported from APEX and REMM.

water leaving the buffer is the amount of water that infiltrated in the REMM buffer.

The REMM simulated average reduction in sediment yield was $24 \%$ for the 3-year study period (Table 7 ). The REMM simulated mass of sediment transport corresponded to the volume of water that was transported. Most of the sediment transport was associated with Hurricane Kyle which had a sum of $469 \mathrm{~mm}$ of rain over a 5-day period, more than four times greater than any other rain event during the three-year study period. Most of the rainfall occurred during the first two days (184 and $226 \mathrm{~mm}$ of rain on September 21st and 22nd, respectively). A likely contribution to sediment transport during the Hurricane Kyle event was the lack of a crop in the field (Table 1), high antecedent soil moisture, and rainfall duration and intensity.

REMM reduced the APEX estimated total N load by $31 \%$. A total of $380 \mathrm{~kg} \mathrm{Nha}^{-1}$ was transported during $2008,13 \mathrm{~kg} \mathrm{~N} \mathrm{ha}^{-1}$ in 2009 , and $12 \mathrm{~kg} \mathrm{~N} \mathrm{ha}^{-1}$ in 2010. Total $\mathrm{N}$ transported during Hurricane Kyle was $333 \mathrm{~kg} \mathrm{~N} \mathrm{ha}^{-1}$ which represented $82 \%$ of REMM simulated 3 year total $\mathrm{N}$ transport. The total mass of $\mathrm{N}$ transported from REMM during the 3-year study represented $69 \%$ of $\mathrm{N}$ fertilizer applied to all subareas. Most of simulated N loss was sediment-N (Table 7); representing $94 \%$ of the total N loads. REMM simulated sediment bound $\mathrm{N}$ transport was $379 \mathrm{~kg} \mathrm{Nha}^{-1}$, a $25 \%$ reduction in sediment bound $\mathrm{N}$ load transport by APEX. The corresponding soluble $\mathrm{N}$ loss $\left(\mathrm{NO}_{3}-\mathrm{N}\right.$ and $\left.\mathrm{NH}_{4}-\mathrm{N}\right)$ in surface runoff for the $3-\mathrm{yr}$ period was $25 \mathrm{~kg} \mathrm{~N} \mathrm{ha}^{-1}$, which was a $69 \%$ reduction of soluble $\mathrm{N}$ transported in surface runoff from APEX. REMM simulated soluble N loss in subsurface flow was $0 \mathrm{~kg} \mathrm{~N} \mathrm{ha}^{-1}$, which was a $100 \%$ reduction of $\mathrm{N}$. On days when fields were irrigated, total $\mathrm{N}$ transported by REMM was $4.8 \mathrm{~kg} \mathrm{~N} \mathrm{ha}^{-1}$, which is $19 \%$ of total $\mathrm{N}$ transported during the 3 -year study. The percent reduction in $\mathrm{N}$ transported on irrigation days from REMM was $60 \%$.

REMM reduced the APEX simulated total P load by $30 \%$ (Table 7). Particulate bound P represented 93\% of total P load from REMM, of which $77 \%$ was generated as a result of Hurricane Kyle. REMM simulated particulate bound $\mathrm{P}$ was a $24 \%$ reduction compared to APEX input. As a result of Hurricane Kyle, of the fertilizer P applied to the upland silage farm during the 3-year period, approximately $6 \%$ was transported from REMM as particulate P. Total P transported by REMM on days where fields were irrigated was $0.09 \mathrm{~kg} \mathrm{Pha}^{-1}$, which is less than $1 \%$ of total P transported by REMM during the 3 -year study period. There was a $62 \%$ increase in total $P$ transported from the upland field to REMM on irrigation days. The $62 \%$ increase was likely a result of fertilizer application timing. 


\section{Summary and conclusions}

APEX and REMM were evaluated for their ability to simulate hydrologic processes and water quality (sediment and nutrients) for the upland silage fields and the adjacent riparian buffer for three years. The models were calibrated and validated for water table depth with $R^{2}$ values ranging from 0.41 to 0.95 , and NashSutcliffe efficiencies ranged from 0.33 to 0.80 , with the exception of subarea 2 of APEX which had a NSE of -3.77 during the validation period. Water table depth parameters that were adjusted in APEX during calibration were not subarea specific; parameter adjustments affect all subareas. Validation of REMM showed that average groundwater $\mathrm{NO}_{3}-\mathrm{N}$ concentrations simulated by REMM were not significantly different from observed concentrations in Zone 3 of the buffer, nearest the field. REMM simulations indicated complete removal of $\mathrm{NO}_{3}-\mathrm{N}$ compared to observed levels near the detection limits for the analytical method. The calibrated and validated models were used to estimate loadings from the fields and the reduction in loading reaching the mangrove wetlands due to the riparian buffer. Three year simulations of the calibrated and validated models are presented as the base case conditions for this portion of the Jobos Bay watershed. The principal outputs from REMM representing potential loadings to Jobos Bay were a result of two tropical systems - Tropical Storm Faye and Hurricane Kyle. For the entire study period, compared to APEX inputs, REMM simulated outputs were $16 \%$ less for total water; $99 \%$ less for subsurface flow, and $24 \%$ less for sediment. Nitrogen and phosphorus loadings from APEX were decreased by $31 \%$ and $29 \%$ in the REMM simulated buffer system, respectively. Simulation results for both models show the importance of timing of extreme events in reducing potential loadings to the mangrove wetlands.

\section{References}

Altier, L.S., Lowrance, R., Williams, R.G., Inamdar, S.P., Bosch, D.D., Sheridan, J.M., Hubbard, R.K., Thomas, D.L., 2002. Riparian Ecosystem Management Model: Simulator for Ecological Processes in Riparian Zones. United States Department of Agriculture, Agricultural Research Service, Conservation Research Report 46.

Blake, G.R., Hartge, K.H., 1986. Bulk density. In: Klute, A. (Ed.), Methods of Soil Analysis, Part I. Physical and Mineralogical Methods: Agronomy Monograph No. 9. , 2nd ed, pp. 363-375.

Gassman, P.W., Williams, J.R., Benson, V.W., Izaurralde, R.C., Hauck, L., Jones, C.A., Atwood, J.D., Kiniry, J., Flowers, J.D., 2005. Historical development and applications of the EPIC and APEX models. Working Paper 05-WP-397. Ames, Iowa: Center for Agricultural and Rural Development, Iowa State University. Available at: <www.card.iastate.edu/publications/synopsis.aspx?id=763>.

Hargreaves, G.H., Samani, Z.A., 1985. Reference crop evapotranspiration from temperature. Appl. Eng. Agric. 1, 96-99.

Inamdar, S.P., Sheridan, J.M., Williams, R.G., Bosch, D.D., Lowrance, R.R., Altier, L.S. Thomas, D.L., 1999a. Riparian Ecosystem Management Model(REMM): I. Testing of the hydrologic component for a coastal plain riparian system. Trans. ASAE 42 (6), 1679-1689.

Inamdar, S.P., Lowrance, R.R., Altier, L.S., Williams, R.G., Hubbard, R.K., 1999b. Riparian Ecosystem Management Model (REMM): II. Testing of the water quality and nutrient cycling component for a coastal plain riparian system. Trans. ASAE 42 (6), 1691-1707

Klute, A., Dirksen, C., 1986. Hydraulic conductivity and diffusivity: laboratory methods. In: Klute, A. (Ed.), Methods of Soil Analyses, Part 1, Physical and Mineralogical Methods. Agronomy Monograph, Number 9. , Chapter 28, pp. 687-734.

Kuniansky, E.L., Rodriguez, J.M., 2010. Effects of changes in irrigation practices and aquifer development on groundwater discharge to the Jobos Bay national estuarine research reserve near Salinas Puerto Rico. U.S. Geological Survey Scientific Investigations Report 2010-5022, 106 p.

Lee, K.H., Isenhart, T.M., Schultz, R.C., 2003. Sediment and nutrient removal in an established multi-species riparian buffer. J. Soil Water Conserv. 58 (1), $1-8$.

Lowrance, R., Leonard, R.A., Asmusssen, L.E., Todd, R.L., 1985. Nutrient budgets for agricultural watersheds in the southeastern coastal plain. Ecology 66 287-296.

Lowrance, R., Altier, L.S., Newbold, J.D., Schnabel, R.R., Groffman, P.M., Denver, J.M., Correll, D.L., Gilliam, J.W., Robinson, J.L., Brinsfield, R.B., Staver, K.W., Lucas, W., Todd, A.H., 1997. Water quality functions of riparian forest buffers in the Chesapeake Bay Watershed. Environ. Manage. 21, 687-712.

Lowrance, R., Altier, L.S., Williams, R.G., Inamdar, S.P., Sheridan, J.M., Bosch, D.D. Hubbard, R.K., Thomas, D.L., 2000. REMM: The Riparian Ecosystem Management Model. J. Soil Water Conserv. 55 (1), 27-34.

Lowrance, R., Williams, R.G., Inamdar, S.P., Bosch, D.D., Sheridan, J.M., 2001. Evaluation of coastal plain conservation buffers using the Riparian Ecosystem Management Model. J. Am. Water Resour. 37 (6), 1445-1455.

Lowrance, R., Sheridan, J.M., 2005. Surface runoff water quality in a managed three zone riparian buffer. J. Environ. Qual. 34, 1851-1859.

Lowrance, R., Williams, R.G., Inamdar, S.P., Bosch, D.D., Sheridan, J.M., 2007. Evaluation of coastal plan conservation buffers using the Riparian Ecosystem Management Model. J. Am. Water Resour. Assoc. 37, 1445-1455, http://dx.doi.org/10.1111/j.1752-1688.2001.tb03651.x.

National Climatic Data Center (NCDC), 2010. NOAA Satellite and Information Service. <http://www7.ncdc.noaa.gov/CDO/cdo> (accessed 27.09.10).

Ncss, 2009. National Cooperative Soil Survey, National Cooperative Soil Characterization Database. Available online at <http://ssldata.nrcs.usda.gov> (accessed 12.03.09).

NERRS (National Estuarine Research Reserve System), 2009. Centralized Data Management Office. <http://cdmo.baruch.sc.edu/> (accessed 5.10.09).

Nash, J.E., Sutclifee, J.V., 1970. River flow forecasting through conceptual models: Part I. A discussion of principles. J. Hydrol. 10 (3), 282-290.

Ritchie, J.T., 1972. A Model for predicting evaporatioin for a row crop with incomplete cover. Water Resour. Res. 8, 1204-1213.

Rollo, N., Robin, M., 2010. Relevance of watershed modelling to assess the contamination of coastal waters due to land-based sources and activities. Estuar. Coast. Shelf Sci. 86, 518-525.

Schaap, M.G., Leij, F.J., van Genuchten, M.T., 2001. ROSETTA: a computer program for estimating soil hydraulic parameters with hierarchical pedotransfer functions. J. Hydrol. 251, 163-176.

SigmaPlot, 2012. Systat Technology, Inc., San Jose, CA <http://www.sigmaplot.com/index.php>.

SSURGO, 2010. Soil Survey Geographic Database. USDA-NRCS <http://soils.usda.gov/survey/geography/ssurgo/> (accessed 4.05.2010).

Srivastava, P., Migliaccio, K.W., Šimůnek, J., 2007. Landscape models for simulating water quality at point, field, and watershed scales. Trans. ASABE 50 (5) 1683-1693.

USDA-SCS, 1984. User's Guide for the CREAMS Computer Model - Washington Computer Center Version. Washington, DC, USDA-SCS TR-72.

USDA-NRCS, 1995. Riparian Forest Buffer, 392. NRCS Watershed Science Institute Seattle, WA.

USGS, 2011. U.S. Geological Survey. Ground water atlas of the United States Alaska, Hawaii, Puerto Rico, and the U.S. Virgin Islands. HA 730-N. <http://pubs.usgs.gov/ha/ha730/ch_n/N-PR_VItext3.html> (accessed 01.06.11).

Wang, X.A., Potter, S.R., Williams, J.R., Atwood, J.T., Pitts, T., 2006. Sensitivity analysis of APEX for national assessment. Trans. ASAE 49, 679-688.

Welsch, D.J., 1991. Riparian Forest Buffers. USDA-FS Publ. No. NA-PR-07-91. Radnor, PA. <http://www.na.fs.fed.us/spfo/pubs/n_resource/buffer/cover.html> (accessed 01.06.11).

Williams, J.R., Jones, C.A., Dyke, P.T., 1984. A modeling approach to determining the relationship between erosion and soil productivity. Trans. ASAE 27, 129-144.

Williams, J.R., Sharpley, A.N. (eds.), 1989. EPIC-Erosion-Productivity Impact Calculator: 1. Model Documentation, USDA Tech. Bull. No. 1768. USDA, Washington, DC.

Williams, J.R., Izaurralde, R.C., Steglich, E.M., 2008. Agricultural Policy/Environmental eXtender Model: Theoretical Documentation Version 0604. BREC Report No. 2008-17. Texas A\&M University. Blackland Research and Extension Center, Temple, TX

Zitello, A.G., Whitall, D.R., Dieppa, A., Christensen, J.D., Monaco, M.E., Rohmann, S.O. 2008. Characterizing Jobos Bay, Puerto Rico: A watershed modeling analysis and monitoring plan. NOAA Technical Memorandum NOS NCCOS 76. 81 pp. 